\title{
Retinoic Acid Receptor Alpha
}

National Cancer Institute

\section{Source}

National Cancer Institute. Retinoic Acid Receptor Alpha. NCI Thesaurus. Code C17533.

Retinoic acid receptor alpha (462 aa, $\sim 51 \mathrm{kDa}$ ) is encoded by the human RARA gene. This protein is involved in the regulation of both retinoic acid-dependent transcription and the cell cycle. 